\title{
Miriam Tlali and Ravan Press: Politics and Power in Literary Publishing during the Apartheid Period
}

Elizabeth le Roux

(University of Pretoria, beth.leroux@up.ac.za)

\begin{abstract}
In a committed anti-apartheid publisher like Ravan Press in the 1970s and 1980s, the selection of authors was usually based on political or ideological grounds as well as the quality of their writing. As a result, Ravan was harassed and subjected to censorship. But to what extent did Ravan's social position and capital inform the author-publisher relationship? One relatively wellknown case is that of Miriam Tlali, described as 'the first black woman to publish a novel in South Africa'. Tlali's account of her relationship with Ravan has been described in very negative terms. However, her account changed over time and is not supported by other evidence. Based on archival sources and interviews, this article will explore the relationship between Tlali and Ravan Press, raising questions of the politics and power dynamics of literary publishing in the apartheid period. The article also raises questions about the methods used to write literary history.
\end{abstract}

Keywords: Ravan Press, Miriam Tlali, publishing history, literary history

\section{Introduction}

Miriam Tlali began writing her first novel in 1964, on an old typewriter. Her struggles to complete the work and then to find a publisher have been told repeatedly, both in her own writing and in numerous interviews. In these, she noted that she held little hope for the manuscript to be published: "I had never really thought it would be published in my lifetime. I had accepted that I had written the book for posterity, for coming generations. I had tried several publishers and everybody had rejected it." A recommendation from the South African Council of Churches eventually brought her to the small anti-apartheid publisher, Ravan Press, in 1974. What happened next has become part of the fabric of Tlali's literary history:

It was like a dream when I walked to their offices carrying the whole manuscript. ... Some months later, they handed me the expurgated version. After I had read it, I was devastated and I sighed, "What have they done to you?" I looked at the pages as if this was a baby I had given birth to, now reduced to shreds."”

The book, Muriel at Metropolitan, was finally published six years after completion, but only after thorough editing and cuts from Ravan. In a later edition, Longman restored these cuts, but the

\footnotetext{
${ }^{1}$ M. Tlali, 'My background and how I began to write', Between Two Worlds (Canada: Broadview Press, 2004), p. 8. ${ }^{2}$ Ibid.
} 
book was then banned in South Africa. This publishing history has been widely repeated in popular and academic writing in reference to Tlali's development as a writer, in part because it is considered to be revealing of the politics and power dynamics of literary publishing in the apartheid period. Given Tlali's status as the first black woman to have a novel published within South Africa and "the only black South African woman to publish fiction in English in the $1970 \mathrm{~s}^{\prime 3}$, the narrative gains added weight, becoming emblematic of the experiences of the black woman writer in South Africa. Moreover, Tlali's own words are privileged in this story, on the basis of interviews, perhaps in an attempt at self-announcement or to break "the silence of a very marginalised group", described as "women fighting their way out of silence to project more authentic images of how women feel and what they do". ${ }^{4}$ These words have been accepted at face value, as both a reliable and authentic record of events. Their intertextual validity has only been supplemented in a few cases, by referring to book reviews ${ }^{5}$ or to the typescript manuscript held in the archives at the National English Literary Museum. ${ }^{6}$ As a result, Ravan Press, in spite of its reputation and record of opposing censorship and providing a platform for black writers, has been accused of censorship itself.

The narrative of a white publisher exploiting a young black writer fits easily into our understanding of the social and cultural dynamics of the era - as John K. Young has elaborated for the US setting, "generally what sets the white publisher-black author relationship apart is the underlying social structure that transforms the usual unequal relationship into an extension of a much deeper cultural dynamic". 8 In South Africa, the situation has similarly been described as a "contested cultural space in which black writing and reading crosses white reading, editing, and publishing". ' South Africa in the 1970s was not a particularly hospitable context for writers, especially those just starting out and more particularly those who were not white and mainstream. The readership was small, especially for local books. There was a highly repressive censorship regime in place, with a newly revised version of the Publications Act (no. 42, 1974).

\footnotetext{
${ }^{3}$ D. Driver, 'Transformation through art: Writing, representation, and subjectivity in recent South African fiction', World Literature Today, 70, 1 (1996), p. 45. Earlier writers, like Bessie Head and Lauretta Ngcobo, were published outside of South Africa.

${ }^{4}$ C. Clayton, 'Radical Transformations: Emergent Women's Voices in South Africa', English in Africa, 17, 2 (1990), p. 27.

${ }^{5}$ M. Schulze, 'The translator as rewriter: the German translation of Miriam Tlali's Muriel at Metropolitan as Geteilte Welt: ein Roman aus Sudafrika' (PhD diss., University of the Witwatersrand, 2010).

${ }^{6}$ S. Nuttall, 'Literature and the archive: the biography of texts', in C. Hamilton et al (eds), Refiguring the Archive (Dordrecht: Springer, 2002).

${ }^{7}$ See for instance M. De Lange, The Muzzled Muse (Amsterdam: John Benjamins, 1997), p. 127.

${ }^{8}$ J.K. Young, Black Writers, White Publishers (Jackson: University of Mississippi Press, 2006), p. 4.

9 A. O’Brien. Against Normalization: Writing radical democracy in South Africa (Durham: Duke University Press, 2001), p. 50 .
} 
As a result, many black authors had gone into exile in the 1960s and those that remained faced an uphill battle in finding receptive publishers. This was also a time when a number of small, independent publishers were being established, in opposition both to the establishment publishers and to the policies of apartheid - and Ravan was one of these courageous new publishers. But it was primarily a context of "structural censorship", ${ }^{10}$ placing many obstacles in the path of black writers: "If one has received an inferior education, lacks fluency in the dominant language (English), lacks access to books and to opportunities for further education and advancement, and if, on top of these disadvantages, one is a black woman, then the chances of one's ever becoming a published writer (in any language) must have been remote."11

Tlali, however, did overcome the obstacle of securing a publisher, and went on to work closely with Ravan Press. Given her complaints about their mutilation of her first novel, we would expect that she would have moved on from Ravan as soon as possible. However, it becomes clear that Tlali complained after the fact, not at once, as she remained closely associated with Ravan at least until Skotaville Publishers was formed in the 1980s. She worked on the literary magazine established by Mike Kirkwood, Staffrider, and published her second novel, Amandla, with Ravan in $1980 .^{12}$ It would certainly appear that this relationship changed over time, to move from a position of acceptance and closeness to anguished accusations of excision and betrayal. How do we understand this shift in behaviour and attitudes? Considering that the validity of memory and oral sources should be "assessed intertextually, through reference to other testimonies and to written documents", ${ }^{13}$ what evidence can be found in the archive that goes beyond Tlali's voice alone? Using a variety of sources - archival documents, both old and new interviews, book reviews, and so on - in this paper, I intend to pose certain questions to the accepted historical narrative, to tease out the power dynamics at work. This enables us to examine the circumstances around the production of Tlali's works, as well as shifts in relationships and in reception.

\section{Contesting the editorial process}

Tlali submitted her work to Ravan Press in 1974. In the foreword to a later edition of the novel, she narrates:

\footnotetext{
${ }^{10}$ P. Bourdieu, The political ontology of Martin Heidegger (Stanford: Stanford University Press, 1991), p. 71.

${ }^{11}$ R. Gaylard, 'Writing black: The South African short story by black writers' (D.Litt diss., University of Stellenbosch, 2008), p. 205.

12 This novel was banned shortly after publication.

${ }^{13}$ B. Harris, 'The archive, public history and the essential truth', in C. Hamilton et al (eds), Refiguring the Archive (Dordrecht: Springer, 2002), p. 176.
} 
At Ravan Press in Braamfontein, I spoke to Mike Kirkwood, a much younger man than the Director, Peter Randall. Mike Kirkwood later informed me that they liked the novel but "... it is too long". He added: "Publishing is an expensive business. We shall have to remove some parts." I objected and said: "But the book will no longer be the same!" And the man, stubborn as ever but smiling, concluded: "Go home and think about it.",

Here, Tlali mentions the role of Mike Kirkwood, although Peter Randall was director of Ravan at this time. In the early 1970s, Ravan had just emerged as a publisher distinct from the Christian Institute and the Study Project on Christianity in Apartheid Society (Spro-Cas), and had a very small staff consisting of only three full-time people. Mike Kirkwood, who was the second director of Ravan after Randall was banned, only started there at the end of $1977 .{ }^{15}$ Since Randall himself was only about 38, it seems most likely that she spoke to him. Indeed, Randall remembers meeting Tlali and receiving the original manuscript, then titled "I am ... Nothing" what he has described as "a large ring binder crammed with disjointed writings including verses and prayers" ${ }^{\text {"16 }}$ and as "a box of papers which lacked coherence, structure or detailed theme". ${ }^{17}$ He says now that it was unpublishable but there was a line running through it nonetheless which lent it potential. ${ }^{18}$ However, it required a great deal of editing to pull it into a publishable shape. This is the usual progression in the publishing cycle, although it can lead to conflict between author and publisher, as Coser points out: "The manuscript, once accepted, must be edited and produced, and the book must be put on the market. In all these areas, much fuel for friction is inevitably present, even though it may never lead to an active clash in specific cases."19

Randall was not yet an experienced publisher, although he had a very keen eye, having accepted the debut novel of an unknown Cape Town academic the year before, after it had been turned down by several other publishers. This was Dusklands, by J.M. Coetzee. This lack of broad experience shows in the correspondence between publisher and authors - in his hesitance over a royalty rate, for instance, or his tentative suggestions of editorial changes. It also shows in Randall asking Peter Struik, of the well-known publishing and bookselling family in South Africa,

\footnotetext{
14 Tlali, 'My background', p. 8.

15 Tlali grew closer to Ravan when Kirkwood became the director, writing frequently to him about her experiences as she began to travel to writers' workshops and conferences around the world.

16 P. Randall, 'The Beginnings of Ravan Press: A Memoir', in G.. de Villiers (ed.), Ravan: Twenty Five Years

(Johannesburg: Ravan Press, 1997), p. 9.

${ }^{17}$ Pan Macmillan Archives - Ravan Press section, 'Muriel at Metropolitan' file (hereafter PMA), G. Moss to C.A. Michael, 17 February 1995. With thanks to Pan Macmillan and the former directors or Ravan Press for access to the archive and for permission to quote. Note that this binder is not in the archives, and is not the same typescript located at NELM, which was typed up by Ravan on the basis of the material submitted.

${ }^{18}$ Interview, 2017.

${ }^{19}$ L.A. Coser, 'Asymmetries in author-publisher relations', Society, 17, 1 (1979), p. 35.
} 
to design Tlali's book and to advise on production issues, including the print run. ${ }^{20}$ And perhaps it shows, too, in his decision to appoint Sheila Roberts, an author rather than an editor, to edit Tlali's manuscript. Roberts' first collection of short stories, Outside Life's Feast, was also published in 1975, and her short stories had appeared in literary magazines like Contrast and Ophir. She had won the Olive Schreiner prize, and was known for her unconventional poetry-prose combinations, what one critic called a "word mosaic". ${ }^{21}$ She was good friends with the artist Wopko Jensma, who had been published by Ravan in 1973, and it is probably through his influence that she was brought into the ambit of Ravan. Randall felt that did an excellent job, producing a "lean and publishable text". ${ }^{22}$ Randall also wrote to Peter Struik, emphasising that the manuscript had been thoroughly edited, and submitted the edited work to Tlali for her approval. ${ }^{23}$

At this point, too, the title was changed, to "Muriel at Metropolitan". The latter title features on the contract: “The publisher agrees to publish the author's book, Muriel at Metropolitan, as edited by Sheila Roberts, and to bear the costs involved." ${ }^{24}$ A significant aspect of the later dispute relates to the selection of the title. Tlali again ascribes the decision-making to bullying by Ravan:

As if to add insult to injury, Mike Kirkwood said: "Miriam, we shall also have to remove the title ... Why don't we just call it 'Miriam at Metropolitan'? ... That sounds nice, actually." And I objected: "No... I will not have my name used like that!” The man again smiled and asked: "How about 'Muriel at Metropolitan' then?"25

I did not want to be associated with it. They had even changed the title. I had called it Between Two Worlds; they said it wouldn't sell under that title, why not call it Muriel at Metropolitan as that recalls my name. I wasn't happy at all about it. ... When I was called for interviews, for write-ups on the novel, I always mentioned that the book had been abridged. ${ }^{26}$

Schulze interprets the change of title as "ideological manipulation by the publisher", and feels that the third title of the work - Between Two Worlds - is the most representative of its actual contents. ${ }^{27}$ This title does not appear in the archival record, except as one of two "other tentative titles" on the typescript: "Them and Us" and "Between Two Worlds". From a publishing

\footnotetext{
20 PMA, P. Randall to P. Struik, 4 April 1975.

${ }^{21}$ Quoted in S. Gray, 'Long Story Short: The Writing Life of Sheila Roberts', Current Writing, 28, 2 (2016), p. 148158.

${ }^{22}$ Randall, 'The Beginnings of Ravan Press', p. 9.

23 PMA, P. Randall to P. Struik, 28 April 1975.

24 PMA, Contract between Ravan Press and Miriam Lehutso (Tlali), signed 7 March 1975.

25 Tlali, 'My background', p. 8.

${ }^{26}$ From an interview with Schulze, 'The translator as rewriter', p. 33.

${ }^{27}$ Ibid., p. 53.
} 
perspective, however, it is considered normal practice to change titles, and it must be admitted that Muriel at Metropolitan is both alliterative and memorable. Longman would later keep this title, for their edition of the work, only changing it in $1995 .^{28}$

Although Tlali says in interviews that she "stopped going to the Ravan Press offices" and took some time to agree to sign the contract, this tension does not emerge in the correspondence between her and Randall. ${ }^{29}$ In these, she appears to play an active role in the production of the book, and accepts many suggestions, while feeling free to reject others: “Thanks for the pageproofs of my book. I have read through them and found very few errors." ${ }^{30}$ She suggests using the name Aggrey instead of Aggripa for the truck driver, and specifies: "Please address me as

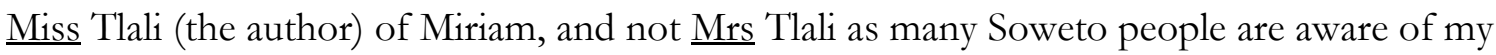
legal name" - her maried name, Lehutso, which is also the name she used to sign the contract. She ends this letter with gratitude and further suggestions: "I have full confidence in everything you have done and are still doing to promote this book Mr. Randall and I am gratefull (sic). I think that it is essential that we have the photo on the back cover of the book so as to arouse the curiosity of the readers." ${ }^{31}$ She later sent two new short stories to Randall, saying "I rely on your judgment as to whether these merit publication", which also shows her view of him as a mentor. ${ }^{32}$ Tlali may have felt constrained in her relationship with Randall, but these sources do not signal any tensions or hesitance on her part. Randall himself remembers the relationship as being polite and formal, but friendly. ${ }^{33}$

Other sources support this initial reading. At least one book review of the time quotes Tlali as being thrilled at the publication of her first novel, and receiving a telegram from her husband, Stephen Lehutso, saying, "Congratulations your brainchild in book form received inspiring paperback copies from publishers. ${ }^{34}$ A similar reaction was mentioned in an interview in 1981: "Miriam was away for almost six months in all [in 1978], and regards the experience as the second most exciting event in her life - the first was when 'Muriel' was finally published". ${ }^{35}$ These reactions reveal excitement about the publishing experience.

\footnotetext{
28 The title Muriel at Metropolitan was kept by Longman for its editions of 1979 and 1988, in the African Classics series. It was only with the Longman Writers Series edition in 1995 that the title Between Two Worlds was used. In 2004, Broadview Press republished Between Two Worlds.

29 'Tlali, 'My background', p. 8.

${ }^{30}$ PMA, M. Tlali to P. Randall, 11 August 1975.

${ }^{31}$ Ibid.

32 PMA, M. Tlali to P. Randall, 7 December 1976.

${ }^{33}$ Interview, 2017.

34 'Metropolitan Miriam', Rand Daily Mail, 17 October 1975.

${ }^{35}$ C. Rolfes, 'Miriam Tlali - feted, berated then banned', Fair Lady, 4 November 1981, p. 66.
} 
Yet in 2004, writing an introduction to a new edition of the work, then titled Between Two Worlds, Tlali said, "... when the book came out, I ran away". ${ }^{36}$ How do we explain this reframing of the relationship? As Tlali later described the editing process, her manuscript was considerably expurgated and abridged - cut "to shreds". The reasons given vary in her different accounts and interviews, from length and economics, to style and genre, to an attempt to avoid censorship. In none of the interviews given immediately following the book's publication by Ravan was the editing mentioned. Her first references to the manuscript being cut may be found in letters to Longman, when she was attempting to secure an international distributor for her work:

I am immensely grateful to Ravan Press for the offer to publish my book. Because the cost would be too high, certain chapters (about five of them) were omitted, also some phrases and paragraphs. I feel that if certain omitted parts (especially the two chapters I am enclosing herewith) were to be included, then certain features of this book will become clearer and more acceptable. ${ }^{37}$

In this case, she alludes only to the costs of publication as a factor in the editing. Other references to editing, and her increasingly emotional response to it, may be found in a series of interviews with academics and journalists, but only from the 1980s, after the longer Longman edition appeared in 1979. Some interviews, while they raise issues of authorship, do not touch on the publishing history of her work. ${ }^{38}$ Other pieces rely on oral testimony without directly stating this, as in the following examples: "Longmans became interested in the book, especially when they learned that certain chapters had been left out. These omissions were made on the advice of the publishers to ensure that the novel would not meet the fate of so much black literature in this country." "39 "Miriam was interviewed, fêted, berated. The book became a best seller. It seemed a classic success story: struggling writer hits the jackpot after the proverbial trudge from one publisher to another ... No matter that she had to compromise by allowing great cuts in the text before it was deemed acceptable for the South African market." ${ }^{40}$

One of the first more negative statements came in an interview with Mineke Schipper during a six-month stay in the Netherlands in 1984, where Tlali expanded on the editing and her reaction to it:

\footnotetext{
36 Tlali, 'My background', p. 8.

37 PMA, M. Tlali to R. Steele, cc P. Randall, 7 December 1976.

${ }^{38}$ For example, J. Seroke, 'Staffriders Speaking: Miriam Tlali, Sipho Separnla, Mothobi Mutloatse. Black Writers in South Africa', Staffrider, 4, 3 (November 1981).

${ }^{39}$ J. Marquard, 'Profile Miriam Tlali', Index on Censorship, 9, 5 (1980), pp. 30-31.

40 Rolfes, 'Miriam Tlali', p. 63.
} 
It wasn't published until five years later [i.e. after completion]. The publisher wanted to make a lot of changes because he was afraid it would be banned. For a long time I refused to give my permission, until one day my mother said she probably wouldn't live long enough to see my book. That was when I agreed to the "censored" version. ${ }^{41}$

Here, Tlali raises the threat of censorship - or self-censorship, to avoid state censorship - as being the main factor behind the editing of her work. She elaborated in a later interview, linking this censorship to the political orientation at Ravan: "I do not want to call this deliberate censorship, but caution on the part of the publishers. They were aware that the book might be banned. That is why they were cautious. You know, these were liberals, and some of our liberals were not very keen that Africans should be educated." ${ }^{42}$ Leaving aside the question of whether Ravan would have supported black writers so adamantly had they not equally supported black education, it is true that Ravan Press was a target for state harassment and censorship. Randall explained to J.M. Coetzee that they were "proceeding with the book as best we can in between court cases, visits from the police and other unsavoury matters". ${ }^{43}$ They accepted a variety of manuscripts from both black and white authors, some of which were banned, including at the time, the poetry collection Cry Rage by James Mathews and Gladys Thomas; Richard Turner's political work The Eye of the Needle; the artist Wopko Jensma's work; and the play Confused Mblaba by Khayalethu Mqayisa. However, there is no evidence to suggest that this led them to tone down the books presented to them on the basis of fear of censorship. ${ }^{44}$ Peter Randall wrote in 1975 to J.M. Coetzee, "If a novel has merit, Ravan will publish it irrespective of possible banning." ${ }^{45}$ Randall himself was subject to a banning order in late 1977. In contrast, one of the mainstream publishers to whom Tlali had submitted her manuscript, unsuccessfully, had indeed raised this issue when rejecting her work for publication: "One publisher quoted the paragraphs which were from Chapter 16 (enclosed) as ominous and a deliberate attempt to incite blacks to strike. Some told me that they would never find a market for a book like that in the country, and that I was wasting my time." ${ }^{46}$

In spite of the misfit between this accusation and Ravan's record, the claim that Ravan Press censored the work continues, being repeated in a variety of sources, as in the following example: "Ravan Press published the novel only after removing certain extracts they thought would

\footnotetext{
${ }^{41}$ M. Schipper, Unheard Words: Women and literature (London: Allison \& Busby, 1985), pp. 59-60.

42 Schulze, 'The translator as rewriter', p. 33.

${ }^{43}$ National English Literary Museum, Ravan Press Collection (hereafter NELM), P. Randall to J.M. Coetzee, 11 January 1974.

${ }^{44}$ Randall does note that he rejected a very small number of manuscripts that would have been immediately banned, as this would have wasted Ravan's scarce resources. Interview, 2017.

${ }^{45}$ NELM, P. Randall to J.M. Coetzee, 21 July 1975.

46 PMA, M. Tlali to R. Steele, 7 December 1976.
} 
certainly offend the Censorship Board — the South African literary watchdog. But despite this effort, the novel was banned almost immediately after publication because the Censorship Board pronounced it undesirable in the South African political context." ${ }^{\prime 47}$ This statement is inaccurate as the Ravan edition was only banned after 1979, when the Longman edition appeared. However, leaving that aside, this is an accusation of self-censorship. Given Ravan's stance on censorship, does it seem likely that the primary motivation for editing Tlali's work was to avoid banning? There could certainly be an element of truth, as all authors and publishers writing at this time would have been aware of the need to find a delicate balance between what was publishable and what was considered 'undesirable'. This explanation, however, only gained currency after the later Longman edition was banned, with a knock-on effect on the Ravan edition. In hindsight, it may appear that Ravan had edited the novel to avoid such a ban in the first place.

However, censorship was not the only factor. A different motivation for the editing was introduced by Tlali in an interview with Cecily Lockett in 1989, where she commented on the suitability of her work for the audience:

I finished writing the first novel, Muriel, in 1969, but it was only published in 1975, and even then too, very much expurgated. A lot of material was removed from it to make it acceptable to the white reader. [Lockett: By whom?] By Ravan Press. Very little editing was done. It was presented the way I had written it, but the thing is, they just expurgated a lot of material from it, which they thought would not be acceptable. So the first version — the South African version — does not have all the right terms, the originality, that I had in my manuscript. ${ }^{48}$

The same reason was repeated to Cheryl-Ann Michael in 1995, who was one of few academics to attempt to balance the story by obtaining the publisher's view. Michael wrote to Ravan: "I spoke to Miriam Tlali about her novel Muriel at Metropolitan, which Ravan published in 1975. I was interested to learn that it was decided to edit the novel, removing views that might offend a white South African readership.... Ms Tlali tells me that she was not consulted during the actual editing process, which cut the novel down by over a hundred pages." ${ }^{\prime 49}$ Glenn Moss, the director at the time, responded with some bemusement and irritation: "anyone familiar with the record and history of Ravan would know that the views of a white readership would have been so far

\footnotetext{
47 T. Mukhuba, 'An Introduction to Miriam Tlali's Muriel at Metropolitan', n.d. Available online http://www.postcolonialweb.org/sa/tlali/mukhuba3.html., n.d. The Ravan Press edition was not banned "almost immediately", but only in 1979 .

${ }^{48}$ C. Lockett, 'Interview with Miriam Tlali', in C. Mackenzie \& C. Clayton (eds), Between the Lines: Interviews with Bessie Head, Sheila Roberts, Ellen Kuгwayo, Miriam Tlali (Grahamstown: NELM, 1989), p. 71.

49 PMA, C.A. Michael to G. Moss, 6 February 1995.
} 
down the list of Ravan's criteria that it would have fallen off the page!" ${ }^{50}$ He proposed a different interpretation of events: "It is quite true that she [Roberts] cut an enormous amount of superfluous material as part of the process of creating a book from a collection of fragments and notes. In doing so, quality and publishability were the only criteria utilised." ${ }^{, 51}$ Peter Randall still supports this interpretation, arguing that the book would have been unpublishable and unreadable without Roberts's intervention. ${ }^{52}$

From Tlali's perspective, 'quality' and 'publishability' were understood quite differently. These elements are both closely related to the third motivation raised for cutting the work, relating to style and genre:

You see, when I took the manuscript to Ravan Press, they said it was too long, but they wouldn't give it back to me. I had no influence whatsoever on how the editor of the book, Sheila Roberts, had rewritten it, and when I saw the complete version I refused to help it appear in that form. I noticed that the portions they had cut were parts where I had made comments. This made me very angry because a major goal of writing this novel was to be didactic. I had decided to use my writing as a platform to inform my people what was happening to us, because with our education system no provisions are made for independent thinking. Furthermore, nobody at that time wrote from our angle. I consciously decided to preach, it was a conscious deviation from narrative norms. What shocked me was that from the very first chapter those sections were omitted where I had commented on what was really happening. ${ }^{53}$

The same reason was discussed in a further interview: "I knew that to write a book where you are busy preaching is not right. You know it's not good literature. I knew all of that and I did not care. I did it deliberately, I preached with the very first chapter. And they [the publishers] left that out with that first issue of the book. They cut out all these parts where I was preaching." ${ }^{\circ 4}$ These didactic qualities would later become linked to the protest literature emerging from South Africa in the later 1970s and early 1980s. Cecily Lockett argues that "Her [Tlali's] project is primarily political and humanistic, rather than aesthetic or formal. Tlali rejects what she terms 'intellectualism' and in her writing often shows little respect for traditional generic categories of 'novel' and 'short story."." While editors may not always understand attempts at genre experimentation, they should remain committed to retaining the author's natural voice.

\footnotetext{
50 PMA, G. Moss to C.A. Michael, 17 February 1995.

51 Ibid.

52 Interview, 2017.

${ }^{53}$ Schulze, 'The translator as rewriter', p. 32-33.

${ }^{54}$ R. Jolly, 'Interview with Miriam Tlali', in D. Attridge \& R. Jolly, Writing South Africa: literature, apartheid, and democracy, 1970-1995 (Cambridge: Cambridge University Press, 1998), p. 144.

${ }^{55}$ C. Lockett, 'The Fabric of Experience: A Critical perspective on the writing of Miriam Tlali', in C. Clayton (ed). Women and Writing in South Africa (Marshalltown: Heinemann Southern Africa, 1989).
} 
However, although "The skill of editing, when done well, is about being sensitive, sensitive to the needs and intentions of the text and sensitive to the concerns of the writer", "there is still an inclination to edit works so that they fit into particular genres aimed at mainstream audiences". ${ }^{56}$ This is where the notion of publishability comes in, as publishers do often attempt to shape works to fit their audience's expectations. In the case of the first locally published black women writer, there would in fact have been few expectations. Moreover, Sheila Roberts' own unconventional use of genre ${ }^{57}$ needs to be more closely examined when considering this claim.

Not all of the studies of Tlali's work have relied on her words alone. Two accounts of the editing have compared Tlali's views with the "neat, original typescript" archived at NELM. ${ }^{58}$ Cullhed describes the editing as a "mutilation", supporting Tlali's account in their interview: "I wouldn't call it edited, except that they took out certain portions. They chopped it up ... they actually removed chapters, paragraphs and so on, that was painful, because it didn't have then all the things that I wanted to sort out". ${ }^{59}$ However, Cullhed does not support the view expressed that this was done to avoid censorship, but rather that "the editing was done to meet the stylistic conventions of fiction, and I would add Western fiction". She repeats the now familiar publication story:

Tlali adamantly defended her typescript version. The publishers' heavy editing, not least their suppression of its original title, which delayed the publication, was a sore point with her, and she only relinquished the original title and accepted the revisions in compliance with her mother's wish to see the book in print before her death. Both the altered title and the novel's heavy editing made the work, in Tlali's words, 'too skimpy, it doesn't have all the corners, all the preaching,' and made her so ashamed of her text that pending its publication she went into hiding in Lesotho. ${ }^{60}$

Sarah Nuttall has similarly argued that the editing involved more than usual editorial intervention. ${ }^{61}$ Using the typescript as the basis for a detailed comparison of different editions, Nuttall suggests that Roberts changed the work's genre, imposing views of how a book should look: "the result not only of what must have been fears of state banning of the text but what we might perceive as the construction of a very particular voice for Tlali based on the liberal-leftist

\footnotetext{
56 A. Heiss, Dhuuluu-Yala: To Talk Straight-Publishing Indigenous Literature (Canberra: Aboriginal Studies Press, 2003), pp. 70-71.

${ }_{57}$ Gray, 'Long story short'.

58 As the academics note, this manuscript does not match the disordered description given by Randall. I would speculate that it is possible that this is not the manuscript originally submitted to ravan, but rather that sent to Longman.

${ }^{59}$ C. Cullhed, 'Grappling with Patriarchies: Narrative Strategies of Resistance in Miriam Tlali’s Writings' (Doctoral diss., Upssala University, 2006), p. 63.

${ }^{60}$ Ibid., p. 69.

${ }^{61}$ Nuttall, 'Literature and the archive'.
} 
suppositions of the Press". Nuttall comments on the lack of correspondence between the publisher and Tlali, and although I have found more correspondence in the Pan Macmillan archives than she had access to, there is little that touches on the editorial stage of production. Her argument, and similarly that of Peter McDonald in his examination of Ravan, is thus more nuanced. ${ }^{62}$

Moreover, these criticisms of the press may be justified by a similar case, as this was not the only time Ravan was criticised by one of their authors for their liberal paternalism. This can be seen in a dispute with Njabulo Ndebele. Ravan was compiling an anthology of black South African poetry, and had chosen the working title of Ask. Any Black. Man, the title of one of the poems contained in the anthology. Ndebele objected, and in fact refused permission for his work to appear in the anthology unless the title was changed. He argued that, "The suggested title really represents no conceptual advance on To Whom It May Concern, a title published by Donker in 1973. ... The liberal publisher was really bringing us out to dance ... Who should ask any black man? Surely not another African. ... The point of the matter is that the suggested title still very much makes Africans alien objects of interest." ${ }^{, 3}$ Ravan accepted this argument, and renamed the anthology The Return of the Amasi Bird. Thus, although they were responsive to criticism, they were at times at odds with the intentions of their authors and were accused of pandering to a white audience even if this may not have been their aim.

\section{Presentation and impact of the first edition}

If we compare the narrative of the production of Muriel at Metropolitan with the material qualities of the book itself, this may shed light on further questions of presentation and representation. Randall was rather pleased with the cover design by Wim Reinders, having taken Peter Struik's advice to spend a bit more on the cover in an attempt to sell the full print run and thus cover all expenses. The image of a woman's head, in shades of black and brown, was seen as striking and effective, although Randall requested that the author's name and the title be made more prominent and legible. The context was an array of mostly black and white covers from Ravan, with some red highlights; Tlali's cover is more graphic apart from the art books published by that time. The back cover image was chosen in consultation with Tlali, while the author profile placed her in a specific geographic but also political context; after emphasising Tlali's education, her financial difficulties, and the link between her experiences and the book itself, the reader is specifically told that "These places [in Doornfontein and Sophiatown, where Tlali grew up] no

62 McDonald, 'Literature Police'.

${ }^{63}$ N. Ndebele, 'Life-sustaining poetry of a fighting people', Staffrider, 5, 3 (1983), pp. 44-45. 
longer exist as a result of the massive removals of Africans from Johannesburg in the 1950s". This is an unusual use of language for an author profile, although what Bourdieu calls the "constituent features" of authors, such as their social origin, are commonly used to situate new authors and their works in the broader literary field. ${ }^{64}$ The blurb then goes on, in an understated manner, to say, "MURIEL AT METROPOLITAN is Ms Tlali’s first book and it represents something of a milestone in the publishing of black writing in South Africa." Again, this is an attempt to situate the work, to indicate that it has a distinct symbolic value and position within the publishing world.

Randall asked Sheila Roberts to write the foreword, which was also used to frame the text in publicity material. Roberts wrote to Randall: "Take a look at this foreword and let me know what you think. I don't think it's quite what you are after or need. Perhaps it sounds too much like a book review?" ${ }^{65}$ When it first appeared in 1975, a quote from Roberts' foreword was carried on the back jacket:

Muriel's story is never strident in hatred or resentment against those who have turned her, in Fanon's words, into 'an object in the midst of other objects'. There is even at times a latent warmth in her attitude towards those 'on the other side', a warmth which she knows they will never allow to develop ... this story should enlighten, surprise and even delight readers, both black and white...

Stephen Gray has described this as "somewhat tongue-in-cheek", ${ }^{66}$ but most reviewers took it quite seriously and academics since then have clearly seen it as a deliberate attempt to tone down Tlali's message and to reassure readers. Peter McDonald, for instance, has referred to this framing as "an exercise in polite literature". ${ }^{67}$ The final line of Roberts' foreword, omitted from the back cover, called for more black writers to get published: “...perhaps it will serve as an encouragement to more black South Africans, at present in silence, to examine and express their lives". ${ }^{68}$

Randall also went to a great deal of trouble to have the book reviewed, writing to outlets that were expected to view the work favourably, such as the Black Sash, the National Council on Women, and the Institute for Black Research: : "I want to tell you about a book we shall be publishing next month, Muriel at Metropolitan, by Mrs M. Tlali. ...The first relevant point is that it

\footnotetext{
${ }^{64}$ Bourdieu quoted in C. Childress \& C. Rawlings, 'Publishers, authors and texts: The process of cultural consecration in prize evaluation', Poetics, 60 (2017), pp. 48-61.

65 PMA, S. Roberts to P. Randall, 3 February 1975.

${ }^{66}$ Gray, 'Long story short'.

${ }^{67}$ P. McDonald, The Literature Police (Oxford: Oxford University Press, 2009), p. 140.

${ }^{68}$ S. Roberts, 'Foreword, in M. Tlali, Muriel at Metropolitan (Johannesburg: Ravan Press, 1975), p. ii.
} 
is by a woman ... The second is that it is by a black woman, which makes it an extremely rare occurrence in South African publishing." ${ }^{69}$ His letter, which echoed several of the points made by Roberts in her foreword, was quoted verbatim in some reviews:

MURIEL AT METROPOLITAN is written by a black woman, which makes it an extremely rare occurrence in South African publishing. ... candour, humour and a generosity of spirit ... The writing is restrained and the effect on many White readers is likely to be one of shocked recognition. ${ }^{70}$

The framing for Tlali's work rests here on her status as one of the first black women writers, on her use of humour and restraint, and, in the review above, on the response of the white audience. Reviewers too commented on these aspects, although they tended to refer to a multiracial readership: "Muriel at Metropolitan is a thought provoking book and should be read by both Black and Whites in South Africa. How each side thinks of the other is shown in such a humorous way none can be offended." ${ }^{, 71}$ Reviews for Muriel at Metropolitan were mostly positive, and several commented on Tlali's unique voice and style (none mentioned the editing or felt it had an impact on Tlali's voice). In addition to reviews in a wide variety of print media outlets, there was also a review on SABC television and on the BBC African Service's "Book of the Day" segment. Many reviews quoted Sheila Roberts' foreword approvingly or echoed the language of Ravan's publicity material. The work “...deserves to become a classic in the history of Black writing in South Africa. ... this book is a model of restrained writing". ${ }^{72}$ It was "An astringent, humorous and good-natured account of her personal experiences while employed as night clerk, typist and shop assistant in Johannesburg..." "73 There were also comments on the genre, with one reviewer (from a conservative newspaper) calling it "social realism" and praising the publisher for producing the debut work: "Nietemin het Ravan Press die Suid-Afrikaanse leser'n groot diens bewys deur hierdie verhelderde kyk in die gemoed van iemand van 'n ander rasgroep vir hom toeganklik to maak" ("Nonetheless, Ravan Press has done the South African reader a great service by making this clear insight into the mind of someone from another race group accessible"). ${ }^{74}$

There were some negative reviews, with the conservative Rapport newspaper criticising the author for being one-sided and for her "shallow generalisation". The reviewer went on to criticise both Tlali and the editors: "Miriam Tlali is a sensitive writer, but she needs better control of her

\footnotetext{
${ }^{69}$ PMA, P. Randall to Black Sash, 17 June 1975.

${ }^{70}$ P. Randall, Sash, 18, 2 (1975), p. 20.

${ }^{71} \mathrm{~J}$. Mkhonza, 'Anything to say? Try writing a book', World, 27 November 1975, p. 3.

72 P. Gibson, 'A Black among Whites', The Daily News, 12 November 1975, p. 35.

${ }^{73}$ Marquard, 'Profile Miriam Tlali', pp. 30-31.

${ }^{74}$ A.P.L., 'Swart vrou in stad', Die Volksblad, 1 September 1976, p. 6; my translation
} 
material. She has the ability to produce a better book. Careless proof-reading does not help her, for instance, on page 57, in a muddled sentence, she reflects to her correct name, Miriam, and not the fictional persona, Muriel." ${ }^{, 75}$ A few critics such as Lionel Abrahams raised questions about the literary merit of the work: "Were it not [a factual record] with, moreover, the stamp of its authenticity on every page, it might scarcely have been worth publishing or reading. As to grandeur of content and aesthetic aspirations, it is a distinctly modest offering. ... in general Mrs Tlali is thoroughly persuasive because her apparently ordinary style represents a rare combination of honesty, perceptiveness, concern and restraint". ${ }^{76}$ The reviewer for the mainstream women's magazine, Fair Lady, was perhaps the least impressed: “...the narrative dribbles along: no highs, now lows, no dramatic moments, no intense involvement with characters. This story could have been enlightening, shocking and even embarrassing to many South Africans. Instead it's a mild yawn."77

Many of the reviews commented more on Tlali's identity than her work: "Here is a rare one - a major book by a Black South African woman". ${ }^{78}$ This is not surprising, given that the paratext marks the novel as being about the black experience, and gives clear indications of the author's racial identity. But is this a case of representing blackness and authenticity of experience to a predominantly white audience? Young describes "an expectation that the individual text will represent the black experience (necessarily understood as exotic) for the white, and therefore implicitly universal, audience", noting that this dynamic doubles in effect for black women writers, who are expected to speak for their gender and race. ${ }^{79}$ This has also been described as "black message/white envelope" ${ }^{80}$ But in spite of the concerns about editing for a white readership, neither the publisher nor the author in this case was deliberately targeting a white audience. Tlali has explicitly said, "When I first wrote I did not even consider anybody but my own people. I was always thinking of a black audience". ${ }^{81}$ And Ravan, because of their political views, always attempted to reach a much wider audience than the polite liberal audience implied by Randall's comment on white readers. A typical view of their role at this time is the following:

\footnotetext{
75 W. Pretorius, 'One-sided record rather than fiction', Rapport, 30 November 1975, p. 23.

${ }^{76}$ L. Abrahams, 'Eloquence of the Ordinary', Snarl, February 1976.

77 G.M., Fair Lady, 18 February 1976.

78 A.R., 'Painting a powerful picture of a big problem', Cape Herald, 1 November 1975, p. 11.

${ }^{79}$ Young, Black W riters, p. 12.

${ }^{80}$ J. Sekora, 'Black Message/White Envelope: Genre, Authenticity, and Authority in the Antebellum Slave Narrative', Callaloo, 32 (1987), pp. 482-515.

${ }^{81}$ J.A. Dean, 'Claiming selfhood: three black South African women writers under apartheid' (MA thesis, University of Wollongong, 1993), p. 114.
} 
In the mid-seventies the South African publishers Ravan Press began to produce novels by black South Africans. The aim was to produce literature by South Africans for South Africans. Ravan Press aims at as wide a readership as possible and tries to keep prices low. They and other publishers of works by black writers, face the financial loss brought by bannings with courage, and will make no concessions by exercising censorship themselves. ${ }^{82}$

Interestingly, given the comment by Barnett about Ravan's accessible prices, one last complaint Tlali raised related to the pricing and distribution: "I complained to Ravan Press that my people would not buy the book as the price was too high - it cost four pounds or something - and that it is only going to be read by whites" ${ }^{83}$ However, the work was not that expensive. Ravan marketing materials show that it was first available for sale at R2,95; Dusklands was much more expensive, at R4,80, in hardcover. The print run sold out, justifying Marquard's comment that "Muriel was an instant success...", although Tlali appears to have been unaware of this: "I'm quite convinced that Muriel at Metropolitan would have been an instant best-seller had it been freely circulated in South Africa". ${ }^{84}$

The aim of keeping prices low was a specific tactic to reach black audiences. This effort, begun under Randall, was admittedly more successful under Mike Kirkwood. In an interview with Oswald Mtshali in 1980, Kirkwood was asked about black messages / white envelopes:

Mtshali: "You are a white man, and a Ravan Press publisher - does this give you the right to be a spokesman on black literature...?"

Kirkwood: "I tried to convey the solidarity that exists between the black writers and Ravan Press as a publishing house." ${ }^{.5}$

In spite of these efforts, Kirkwood was later rocked by accusations of paternalism himself, when a group of his black colleagues at Ravan broke away to form Skotaville Publishers - a publisher dedicated to "publishing black writers, under black control from start to finish", according to their publicity material. Tlali would serve on the board of Skotaville.

Was Tlali's experience typical or not? Was she treated differently because she was a woman, a black woman, a first-time author? A similar example may be identified at David Philip Publishers, also an oppositional publisher in the 1970s and 1980s - that of the author Sindiwe Magona. Marie Philip remembers:

82 U. Barnett, A Vision of Order (Cape Town: Maskew Miller Longman, 1985), p. 157.

${ }^{83}$ Schulze, 'The translator as rewriter', p. 34.

${ }^{84}$ Marquard, 'Profile Miriam Tlali', p. 30; M. Mphahlele, 'Writing as transformational: A marxist feminist analysis of Miriam Tlali's works' (MA thesis, Simon Fraser University, 1993), p. 88.

85 O. Mtshali, 'Black witers aiming at "liberation", Cape Herald, 2 August 1980. 
We knew to be cautious in launching Sindiwe. Her script covered a span of time ... It was sparky, full of humour and vitality, but we thought it was too long and would be expensive for an introduction to the market. We persuaded a reluctant Sindiwe to let us split it in two... ${ }^{86}$

Magona, however, has said nothing about her publishing experiences, in spite of fairly drastic editorial intervention. Similarly, Madlala has interviewed a number of women writers, many of whom related problems with finding a publisher, but none of whom complained about the publishing process. ${ }^{87}$ A contrasting case is Ravan's relationship with J.M. Coetzee, revealing limited editorial intervention at Coetzee's insistence. Randall explained to a reviewer about a perceived publisher error: “...I can assure you that the author's intention was quite deliberate. I took this up with him after a first reading of the manuscript and again subsequently, since I too was sure that it was a mistake, and even now I don't fully understand what he meant by it. The author's wish must, however, prevail." 88 While Coetzee exercised an unusually thorough oversight over his books, he was also a debut author, but he was treated differently from almost all other authors at Ravan, apart from Nadine Gordimer. ${ }^{89}$ Other inexperienced authors were not unhappy with their treatment at Ravan. For instance, Petrus Tom has thanked his editor, saying:

Before I met Judy [Maller] I didn't think I could write a book, but she encouraged me and introduced me to Ravan Press. Sometimes I felt like giving up writing this book because I got lazy and became confused about what to put in and what to leave out. But I am very happy that I continued so that through this book the world will know me better. $^{90}$

Clearly, some authors were more secure in their position to negotiate more editorial control, and these were largely white authors. However, the record shows that Ravan tried to do their best by Tlali, positioning her text in what they considered a saleable manner. They were successful in avoiding banning and in circulating the text fairly widely within South Africa. Reviews of the time were mostly extremely positive, and this launched Tlali's career and her reputation.

\section{The Longman edition - and banning}

The Ravan edition was not the end of the publishing history of Muriel at Metropolitan. Almost at once, Ravan sought an international co-publisher or distributor. One of these was Heinemann Educational Books, under James Currey, who turned it down : "I thought you might like to see

\footnotetext{
${ }^{86}$ M. Philip, Books that Matter: David Philip Publishers during the Apartheid Years (Cape Town: David Philip, 2014), pp. 91-92.

${ }^{87}$ N. Madlala, 'Making it into print: Writers Talk About it', Agenda, 16 (2000), pp. 48-54.

88 NELM, P. Randall correspondence, 17 June 1974.

89 See Wittenberg for a more complete discussion of the publishing of Coetzee. H. Wittenberg, 'The Taint of the Censor: J. M. Coetzee and the Making of "In the Heart of the Country", English in Africa, 35(2) (2008), pp. 133-150. ${ }^{90}$ P. Tom, My Life Struggle (Johannesburg: Ravan Press, 1985), p. i.
} 
this reaction by an East African reader even though it is not sufficiently positive to take up your offer to subcontract." The reader's report Currey referred to was blunt in its dismissal of the work: "All said, where is the story? With consideration of the present atmosphere in Soweto and other black townships - isn't Tlali's voice too feeble?"'1 A better response was received from Longman, after a long correspondence. A memo from Bing Taylor, to the Johannesburg office noted: "I have finally had a chance to read Muriel (sic) Tlali's book and I agree that it is very good and deserving of a wider distribution than Ravan Press could provide." ${ }^{.2}$ In spite of an initially fairly negative report from Michael Echeruo of Longman's African Creative Writing Series - "I didn't find Tlali's novel particularly thrilling"93 - the novel was eventually accepted for the new Drumbeat series. This series, established in 1979, was described by Longman as a "popular paperback series of African and Caribbean fiction, plays and poetry. The series includes established best-sellers, new works by successful authors and first novels by new writers."

Tlali was particularly keen to ensure that the Longman edition contained the material that had been cut from the Ravan edition. To a large extent, this was the case, although Longman also had the manuscript edited and cut some of the material which they also considered superfluous. The cover design changed, to feature two hands on a typewriter against a blue blackground, bt the title was retained. The editor commented to Tlali: "We considered the alternative titles you suggested but did not feel that any of them was quite right. The original title is not perhaps ideal but it is accurate and alliterative!" 94 The new edition appeared in May 1979, and was intended for distribution in Southern Africa (apart from South Africa) as well as internationally. But this was not to be: copies shipped to South Africa were embargoed and then banned.

Confusion quickly arose between the two editions, with booksellers refusing to order either, to avoid sanction. Ravan themselves were unsure of the status of their own edition:

[Marilyn] Kirkwood of Ravan Press then approached a member of the Directorate of the Publications Appeal Board and was firmly told that both Muriels were banned because the two editions were in fact identical. Mrs Kirkwood pointed out that this was demonstrably not the case. ${ }^{95}$

The unabridged edition from Longman was considered highly racist by the censors, and it was banned due to descriptions "calculated to injure the relationship between white and black",

\footnotetext{
91 PMA, J. Currey to S. Gray, 14 October 1976.

92 PMA, B. Taylor to R Steele, 2 August 1976.

93 PMA, M. Echeruo to B. Taylor, 1976.

94 PMA, N. Marson to M. Tlali, 30 June 1978.

${ }^{95}$ Marquard, 'Profile: Miriam Tlali', p. 30.
} 
according to the censor's report. Ravan appealed the ban, because the books actually differed, but they were unsuccessful. A newspaper report on the banning refers to the reasons raised by the censors - but also reflects the confusion between the Longman and Ravan editions and their part within the publishing history:

A novel, Muriel at Metropolitan, was found undesirable in terms of the Publications Act earlier this year because an Afrikaans-speaking woman was referred to in dialogue as a 'lousy Boer', and 'derogatory remarks' were made about Afrikaners. The book, published by Ravan Press, was a revised version of the book with the same title published by Longman and found undesirable earlier. ${ }^{96}$

Commentary typically raised the point that Ravan's editing must have been done to avoid such a ban in the first place: "Die hersiende Drumbeat-weergawe sluit bygevoegde materiaal in wat weggelaat is uit Ravan-Pers se weergawe weens moontlike sensuurprobleme" ("The revised Drumbeat edition includes additional material which was left out of Ravan Press's edition to avoid possible censorship problems"). ${ }^{97}$ Tlali's response was also usually described: "Miriam Tlali naturally feels some resentment at the summary treatment of her Muriel. The book was doing well, the first printing had sold out and a second was in preparation. She has refused to appeal against the banning order." "Well, obviously it was disappointing. But I have always believed that if the system objects to my work, I must be on the right track." "When my first book was banned, I felt as if someone had placed a thick wall between me and my people. I never thought I could live to see the day when my books could be read in my own country.",100

The confusion around these editions has persisted in the academic literature, with some academics seemingly unaware of whether they are using (and quoting) the Ravan edition (1975), the first Longman edition (1979) or a later Longman edition. For instance, Cullhed notes in her study that she will be quoting from the Longman edition of 1975 - an edition that does not exist. ${ }^{101}$ Barker, in his study of Muriel, uses only the date (1994) as a reference, with no publisher mentioned at all, and no reference to any aspect of the publishing or wider context. ${ }^{102}$ There is no 1994 edition, but this may refer to a reprinting of the 1979 or 1988 Longman editions. This may seem a minor matter, but if it is precisely the point of some of these academics that Tlali's intentions were disregarded in the Ravan edition and that the Longman edition is somehow

\footnotetext{
96 'Novel 'derogatory' to the Afrikaners', The Argus, 25 September 1979, p. 18.

${ }^{97}$ W. Pretorius, 'Ja, waarlik - Muriel is ook in die laai', Rapport, 25 November 1979, p. 22; my translation

98 Marquard, 'Profile Miriam Tlali', p. 31.

${ }_{99}$ M. Mosotho, 'Metropolitan Miriam', Tribute, August 1987, pp. 36-37.

100 'Miriam Tlali, author', Tribute, August 1996, p. 40.

101 Cullhed, 'Grappling with Patriarchies'.

102 D. Barker, 'Performativity, subjectivity and gender: an inquiry into the applicability of theoretical concepts to Muriel at Metropolitan' (MA diss., University of South Africa, 2009).
} 
more authentic, then it is necessary to be absolutely clear on which edition of the work is being discussed at which point.

\section{Conclusion: A changing relationship}

How do we account for the changing accounts of the relationship between Tlali and Ravan Press? Part of the reason could be a change in how Tlali perceived the relationship over time. One factor was her growth in confidence and status as she became better known. From about 1978, Tlali was invited to writer's workshops and began to attend conferences internationally, where she also received advice from other writers. This advice may not always have been legally accurate, as the following example shows: "During her overseas visits, Tlali was shocked to find that many of her works had been published without her consent. Copyright had simply been ignored, and she had received no payments from the publishers." ${ }^{\text {103 }}$ The origins of this complaint could not be traced, as in the Ravan and Longman cases, copyright and contractual obligations were in fact adhered to. However, her unhappiness led her to try her hand at publishing: 'Described by at least one young writer as 'aggressive', angered by what she sees as interference from publishers - even the normal course of editing - she tried becoming her own publisher before she discovered how much money and time it required". ${ }^{104}$

This raises the factor of money: Tlali's ongoing financial difficulties and what she perceived as disappointing royalties: "She has never been financially satisfied with the sales of her books, and has always had to struggle to make a living. ... 'The royalties I got from the sales abroad were very small. Exploitation starts with the publishers. We have a lot of them asking for the books, but we only get a small fraction of the profits'." ${ }^{105}$ The Longman royalty of $25 \%$ on the licensed first printing of 20,000 copies was divided, contractually, between Tlali and Ravan Press, while other international royalties (for instance, for the Dutch and Polish editions) were channelled via Longman to Tlali. Ravan's records indicate that they paid these amounts to her, but her agent, Tony Peake, later negotiated to receive the royalties directly from Longman to speed up the process. From the beginning, Tlali saw her writing as an income generator, but the archive shows that she was unable to live off her earnings: in 1977, "Miriam is in financial trouble - her husband is unemployed, and her daughter is due to go to school in Lesotho, with fees to be

\footnotetext{
${ }^{103}$ Mosotho, 'Metropolitan Miriam', pp. 36-37.

104 B. Ludman, 'An angry writer mellows - but still fights the silencers', Weekly Mail, 10-16 March 1989.

105 Quoted in S. Kooma, 'Mirriam's still as sweet as ever', Sowetan, 12 August 1985, p. 8.
} 
found as well as the usual survival money. She feels full of writing at present, and would love to be able to write full time. But must work to keep the family going."106

Apart from these issues, Tlali clearly experienced the publishing of her first work as a painful one - at least in retrospect. Her experience with Ravan affected her later relationships with other publishers, too. For instance, when publishing Footprints in the Quag with David Philip Publishers in the late 1980s, Tlali did not accept many of the editorial changes and suggestions made, including the question of who would write a foreword and what the title should be. The editor, Karen Figes, was sympathetic (although inaccurate), writing to Marie Philip: "You do have to be a little understanding of Miriam's apprehension for she has had bad experiences in the past with Ad Donker and so needs reassuring"' ${ }^{107}$ However, this did not stop the co-publisher, Pandora, from using the title Soweto Stories instead of Footprints.

Our understanding of the author-publisher relationship also relates to the methods used to write literary histories, and especially the use of interviews and first-person accounts, often unsupported by other sources. John Stotesbury, who himself has conducted and published interviews with authors, reflects on this method, noting, "It appears virtually impossible to find any discussion of the textual status of the literary interview-whether, for instance it can be regarded not only as a metatext but also, perhaps, in some circumstances as a potential paratext, that is, a kind of half-way house functioning both as a critical text and as a semi-autonomous literary text produced in collaboration with the interviewer". ${ }^{108}$ The problems of reliability associated with historical sources - problems of bias, selectivity, motive, authenticity, etc. - are important when tracing literary and publishing histories. In particular, the use of oral interviews opens the door to unconscious bias. In this paper, I have made a deliberate attempt to use a broader range of sources; inevitably, these too contain bias, and it is true that written sources are not necessarily less biased than oral ones. However, they represent the perspectives of other agents in this history, which have not previously been taken into account. When put together with the changing account from Tlali, they provide a more complex picture. While the discourse of authenticity, in which the author's view is seen as somehow more true and less filtered by commercial motives than the publisher's, remains widespread, the author's perspective on a relationship with a publisher is not the only one. An attempt should be made to capture a greater diversity of voices and views.

\footnotetext{
106 PMA, notes from a "Conversation with Miriam Tlali", 20 December 1977. ${ }^{107}$ NELM, K. Figes to M. Philip, 11 July 1988.

${ }^{108}$ J. Stotesbury, 'Interviewing African Writers', Nordic Journal of African Studies, 7, 2 (1998), p. 29.
} 
Nuttall suggests in this regard that we should be asking "a very particular set of questions for the literary archive - questions about the nature of subjectivity and language, which are also questions about literature, history and identity and their relationship to truth. Who owns the facts of our lives?" 109 Referring both to Miriam Tlali and Bessie Head, she argues that their biographical comments should be "read as strategic statements made to different audiences on different occasions". ${ }^{110}$ In this article, Nuttall both raises the idea of authors as unreliable narrators of their own biographies, and suggests that this fluidity does not really matter. The framing of this particular account on the basis of hindsight reflects such a fluidity: Tlali's accounts are inconsistent and even in some cases inaccurate. Whether this is deliberate or not is open to interpretation, but Tlali has played a significant role in controlling perceptions of her identity and her writing. As Glenn Moss commented, "I do not believe that she did not see and approve the edited version of her manuscript, and suspect that there may be certain post facto reconstructions of history taking place". ${ }^{111}$

If the core issue comes down to social value and capital, as Nuttall and others suggest, it becomes an interesting assumption that Ravan Press, working outside the mainstream of established publishers, still managed to deploy greater cultural authority than Tlali. In fact, I would argue, the opposite has been true in this case, with Ravan being positioned as exploitative and Tlali as the authentic voice. While Tlali emphasises her powerlessness and lack of influence, and the lack of room for negotiation or compromise in the editing process, the evidence does show that she intervened in decisions at the proofreading stage and around the cover. While Ravan may have been paternalistic, their efforts to publish and distribute her work were sincere and effective. At the same time, the editing process was clearly unpleasant for Tlali, and affected her increasingly over time. Existing accounts of the publishing history of Muriel depict Ravan as being at best cautious, and at worst exploitative and engaged in censoring their own authors. This does not fit with other accounts of Ravan and deserves further explication. The narrative of a greedy, white publisher and a young, black author with no agency is compelling but ultimately unhelpful, as is the continuing insistence that white editors cannot edit black authors without compromising their voices.

\footnotetext{
109 Nuttall, 'Literature and the archive', p. 293.

${ }^{110}$ Ibid., p. 294.

111 PMA, G. Moss to C.A. Michael, 17 February 1995.
} 